\title{
The research on the restriction factors of education informationization in the special difficult area of Liupanshan
}

\author{
Yamei Mu \\ Gansu Medical College, Pingliang Gansu China \\ mym622@163.com
}

Key words: the six panshan concentrated contiguous area, education informationization, education reform, influencing factors

\begin{abstract}
: the development of information technology has a huge impact on education reform, to explore Liupanshan concentrated special difficult areas the influence factors of education informatization reform, as well as the relationship between them, is a common concern for domestic educators and researchers. This article through to Liupanshan concentrated special difficult areas of primary and secondary schools, sampling, analysis and combing the influence factors of the present stage in the process of implementing the education informationization, design the analysis framework, through expert assessment, form factor chart, at the same time, the relationship between various factors.
\end{abstract}

\section{Introduction}

The development of information technology in promoting local education reform and development of mountainous area plays an important role, the Chinese government attaches great importance to the role of education informatization, and in the national medium and long-term education reform and development plan outline (2010-2020) "clearly pointed out:" must attach great importance to the revolutionary influence to the education information technology". The report of the 18th national congress of the communist party of China stipulates that the implementation of education modernization in 2020 will be basically realized, and the fourth plenary session of the 18th CPC central committee will further clarify the objectives of "the important progress made in the modernization of education". To complete the building of a moderately prosperous society in all respects, we must ensure that the fruits of the modernization of education provide the personnel guarantee and intellectual support for economic and social development [2]. From the actual situation of education application of information technology, teaching management and education teaching have become the normal state of education development. However, in the process of national implementation of a series of major projects, in the process of into the rapid development of education informatization, education informationization development is faced with uneven regional development, remote mountain high quality teaching resources shortage, low utilization rate of severe challenges. So the Liupanshan concentrated special difficulties in education informationization to promote education teaching change factors and the relationship among these factors, for education in the rural informatization development, the promotion of basic education reform is of great importance.

The central contiguous area of Liupanshan is one of the 14 central contiguous areas of the country, which is the main battlefield of the national poverty alleviation. This area is 15.27 square kilometers of area, covering west solid region in Ningxia, Shaanxi bridge in Shanxi region, central and eastern regions in Gansu and Qinghai eastern region, a total of 61 counties (districts), involved more than 2000 [3] in the population. Since the implementation of the education stage curriculum reform, the education has undergone tremendous changes in both form and content after more than 10 years of reform and promotion. Liupanshan concentrated destitute areas in education reform 
already exists in the basic education in the developed area, and has its own particularity, summarizing the common experience of education reform at the same time, to find and timely insight into the problem of education research. New media technology prospectlog in mount Liupanshan concentrated destitute areas of application, teachers change the ideas and methods of teaching, stimulate students' interest, make up for the inadequacy of traditional teaching, improve teaching efficiency, improve teachers' information literacy, stimulate the school's leadership; The popularization and improvement of technology can be adopted in various forms, such as "one-to-many" training, "many-to-many" discussions, etc. It is very important for strengthening the reform of education informationization, improving teaching quality and teaching quality in the central contiguous area of Liupanshan.

This study firstly interprets the feasibility analysis of the new media technology on the basis of education's fair implementation in the central contiguous area of Liupanshan. Again from the case of education informationization to promote education reform at home and abroad, put forward the education informatization of Liupanshan concentrated destitute areas the influence factors of basic education fair implementation framework, inviting peer experts to evaluate its at the same time; Finally, using the data analysis, get the new media technology to promote Liupanshan based education fairness to realize the influence of concentrated destitute areas, for Liupanshan concentrated destitute areas in-depth development of education informationization, to promote the destitute areas of basic education fair development to provide security and enlightenment.

\section{The feasibility analysis of education fairness in the central contiguous area of Liupanshan is realized}

New media technology is the use of digital technology and network technology, through the Internet, wireless communication network and satellite channels, such as TV, computer and cell phone as a terminal, to provide users with video, audio, voice and data services, interactive information and entertainment services such as remote education, its biggest characteristic is to melt the between regions, administrative, and even between communicators and recipients of the border.

In recent years, the country has given a lot of attention and support to the development of education informationization in the special area, taking various measures to accelerate the construction of education informatization in this area. For example, "the rural elementary and middle schools modern distance education pilot demonstration project", etc., for schools to implement project engineering, modern distance education coverage area is wide, the primary and secondary school construction there is a teaching CD play point, the satellite education viewpoint, multimedia classrooms, etc. At the same time, continue to actively strive for the national financial support for schools of various levels or computer facilities, electronic whiteboard, etc, the construction of campus network, recorded the classroom, the campus digital broadcasting system, installation for the whole campus security video surveillance system, enhance the level of education informationization and campus security and stability of person ability.

In information technology and new media technology rapid development today, "Internet +", cloud computing and Internet of things technology has on human life and the study way has a great influence, has been deep into the Liupanshan concentrated destitute areas in people's life and work, to Liupanshan concentrated destitute areas of social economic development, the Liupanshan concentrated destitute areas education teaching reform and the fairness of education is placed great hope, also to support Liupanshan concentrated destitute areas education teaching reform, enlightenment and to provide a basic education fair implementation possible.

\section{Technical route analysis}

The development of education information in countries such as Britain and America is very typical. Countries such as Intel's draft - information technology monitoring framework, Britain's schools information education informatization development level comprehensive framework, Irish information-based learning map, etc., are all information of the dimensions of teaching reform and 
technical indicators, through the study, in order to better help educators and administrators development of education informationization in this region, we will accelerate reform of the district education. As shown in table 1, education informatization promotes basic education teaching reform typical case framework.

Table 1. Education informatization promotion basic education teaching reform typical case framework

\begin{tabular}{cll}
\hline Order & dimensionality & index \\
\hline 1 & Information leadership; & $\begin{array}{l}\text { School planning, information value } \\
\text { identification, change strategy }\end{array}$ \\
\hline 2 & $\begin{array}{l}\text { Teacher professional } \\
\text { development policy }\end{array}$ & $\begin{array}{l}\text { Teacher training, teaching research support, } \\
\text { teacher development }\end{array}$ \\
\hline 3 & Student ability & Student literacy \\
\hline 4 & Teaching methods I & $\begin{array}{l}\text { Innovation of teaching mode, reform of } \\
\text { teaching mode, reform of evaluation }\end{array}$ \\
\hline 5 & Digital resources & $\begin{array}{l}\text { Resource construction, availability of } \\
\text { resources, sharing and openness }\end{array}$ \\
\hline 6 & Learning environment & $\begin{array}{l}\text { Physical learning space, network learning } \\
\text { space }\end{array}$ \\
\hline 7 & Academic evaluation & School records and graduation rates
\end{tabular}

In this paper, the influence factors of education informationization at home and abroad are studied, and the influence factors of education reform and the relationship between them are summarized. Therefore, in the study, first of all need to be solved is how to describe and analyze the education informatization promotes the development of teaching reform, education informationization to promote education reform and research of the key factors and the relationship between them. In the research method, literature research, case analysis and data modeling are adopted. The specific research route is shown in figure 1:

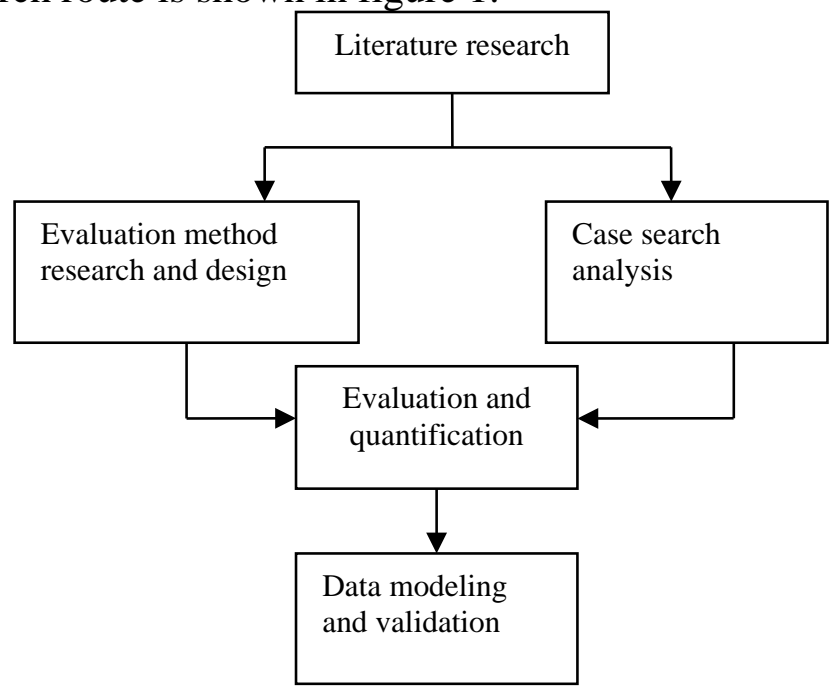

Figure 1 research route

Combining with the existing foreign information analysis framework, using the literature method to determine the impact analysis framework of the reform of education informatization, and then select Liupanshan concentrated destitute areas differences of 20 school case analysis, finally invited county bureau of education as well as some experts, a total of five colleges and universities, with the method of five-point scale scores evaluation, finally calculate the average scores of each dimension, such as a middle school in each dimension score table listed in table 2. 
Table 2. Data of each dimension of a middle school

\begin{tabular}{cccccccc}
\hline $\begin{array}{c}\text { Ordinal } \\
\text { number }\end{array}$ & dimension & Expert1 & Expert2 & Expert3 & Expert4 & Expert5 & average \\
\hline 1 & $\begin{array}{c}\text { Information } \\
\text { leadership }\end{array}$ & 4 & 5 & 5 & 4 & 5 & 4.6 \\
\hline 2 & $\begin{array}{c}\text { Teacher } \\
\text { professional } \\
\text { development }\end{array}$ & 4 & 4 & 4 & 4 & 3 & 3.8 \\
\hline 3 & $\begin{array}{c}\text { Students } \\
\text { ability }\end{array}$ & 3 & 3 & 4 & 4 & 3 & 3.4 \\
\hline 4 & $\begin{array}{c}\text { The teaching } \\
\text { method }\end{array}$ & 3 & 3 & 4 & 3 & 4 & 3.4 \\
\hline 5 & $\begin{array}{c}\text { Digital } \\
\text { resources }\end{array}$ & 3 & 3 & 4 & 3 & 4 & 3.4 \\
\hline 7 & $\begin{array}{c}\text { The learning } \\
\text { environment }\end{array}$ & 3 & 3 & 4 & 3 & 3 & 3.6 \\
\hline $\begin{array}{c}\text { Academic } \\
\text { evaluation }\end{array}$ & 4 & 4 & 3 & 4 & 3 & \\
\hline
\end{tabular}

Note: 1- poor, 2- poor, 3- general, 4- better, 5- good.

The influence factor model [4] is obtained by comprehensive calculation and analysis. See figure 2.

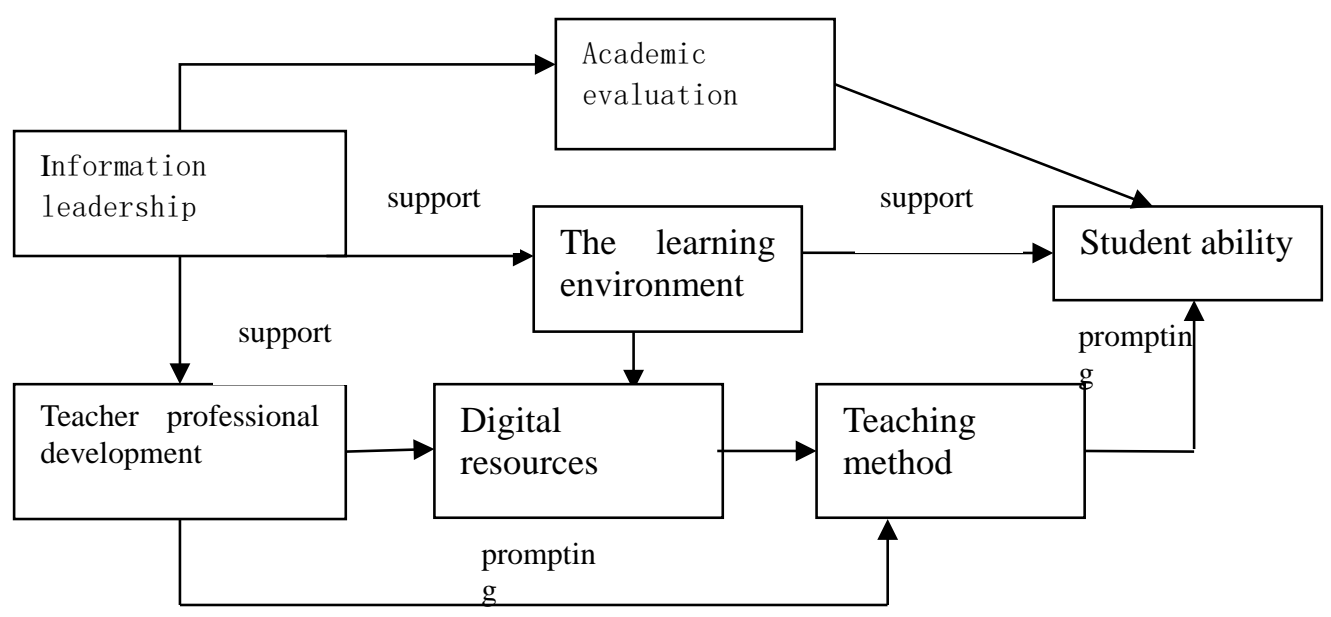

FIG. 2 influence factor model

\section{Analysis of influencing factors}

Europe and other countries of the education informatization is developing very fast, very significant results, as in the collection of European national center for education information technology development, such as the evaluation framework of [5], and on the basis of the analysis of these frameworks to summarize, Jiangsu and other provinces in China [6], and the particularity of the education informatization of Gannan Tibetan areas, and according to the expert scoring, after analyzing the data, puts forward the Gannan Tibetan areas influence the education informatization promotes basic education key influencing factors, as shown in table 2, which includes five dimensions, 10 indicators, covers the leadership, teachers' professional development, and students' ability of digital resources, etc. Listed in table 3. 
Table 3 influencing factors

\begin{tabular}{lll}
\hline $\begin{array}{l}\text { Influencing } \\
\text { factors }\end{array}$ & Five dimensions & Ten indicators \\
\hline 1 & Leadership & $\begin{array}{l}\text { Identification, school vision, change } \\
\text { strategy }\end{array}$ \\
\hline 2 & $\begin{array}{l}\text { Teacher } \\
\text { professional }\end{array}$ & Training, policy incentives \\
\hline 3 & Digital resources & Resource sharing, resource building \\
\hline 4 & Evaluation & Graduation rate and innovation activities \\
\hline 5 & Student ability & Way to change \\
\hline
\end{tabular}

\section{Relationship model between factors}

Informationization leadership on teachers' professional development and applications of digital resources has a positive promoting role, teacher's professional development on teaching methods, learning style has a direct and positive influence, is the main body of teaching information change, construction and sharing of digital resources has obvious effect, in turn, the digital resources of teaching methods and teachers' professional development has a great influence. The fundamental goal of informatization reform is to promote the development of students' ability. Students as a new generation of learners, becoming an information based society puts forward new requirements on their ability, put forward by the domestic common is the "core literacy in the 21st century", critical thinking, problem solving, communication and coordination ability and the ability of creation and innovation [7]. Education informatization promotes Liupanshan concentrated destitute areas education focuses on course change form, learning contents, teaching activities and study way, through a series of change to promote students' core literacy in the 21st century [8]. See figure 3.

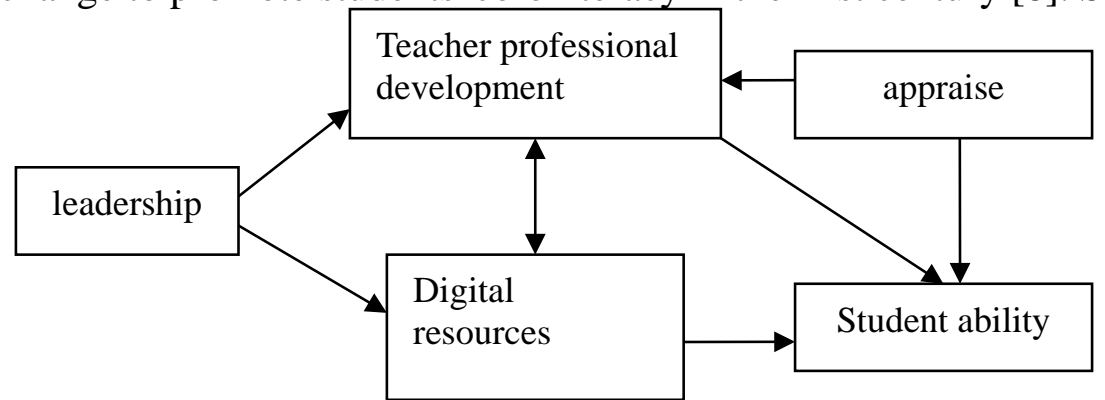

FIG. 3 relationship model between various factors

The whole area of the Liupanshan concentrated contiguous area promotes education informationization, which should be adopted from small scale, from point to surface and layer by layer. Cities and counties in primary focus, school leaders attach importance to, the school vision, policies, increasing the financial input in school information, reflect the principal role of teachers, through the investment of hardware devices, drive teacher's teaching mode innovation, driving training mode reform, the new model was applied to the classroom and extracurricular activities.

The government, the education bureau and the relevant departments at all levels should attach great importance to the school education informatization development, should first determine the clear development plan in the development plan, formulate feasible and effective incentives to ensure the system to the ground; Hardware devices are considered in multilateral financing, construction of computer classroom, construction of excellent teaching database, digital resource construction of satellite network, access to high-quality learning resources, narrow the gap with developed areas, realization of education fairness. Teaching mode by a single way of teaching and learning to learn and auxiliary, teaching a variety of teaching methods, changing teaching mode is bound to drive continuously strengthen teachers training, constantly improve the level of business, continuous innovation, reform efforts will be used in actual teaching, the first selected pilot school, 
extra-curricular activities at school to the innovation of classroom striding forward, try out a period of time, in teachers, students, parents and society evaluation, such as good effect, steadily further promotion.

\section{Conclusion}

This study combines the foreign part of the school education informatization analysis framework, domestic education informationization to promote the reform of basic education teaching cases, analyze the domestic mature case, combining with the features of the basic education in Liupanshan concentrated most needy, invite experts to measure, the influence factors of informationization to promote education reform model is set up. Analysis and combing the influence factors of the present stage in the process of implementation of the education informationization, at the same time, it illustrates the relationship between the various factors, in order to promote Liupanshan concentrated destitute areas education informatization reform provides direction and countermeasures.

\section{Acknowledgements}

Project name: university research fund project in gansu province: "research on the restriction factors and countermeasures of education informationization development in the special difficult area of Liupanshan," project number: 2016a-114

\section{References}

[1] zhu xuefeng yuan juanjuan. The information leadership investigation and reflection of the principal in rural primary and secondary schools in the underdeveloped areas of northwest China. The case of $\mathrm{Y}$ county in gansu province is the example [J]. Contemporary education and culture, 2014(1):66-72.

[2] li hua shu, zhang shishuai. On education for people's services [J]. Journal of chengdu university of traditional Chinese medicine (education science edition), 2007(2):10-12.

[3] zhang lihui. Let the six mountain areas focus on the area of the special area of the area.

Net/yaowenjujiao /2016-03-04/599. The 2016-03-04

[4] zhang wenbo. Current situation and countermeasures of education information development in primary and secondary schools [J]. China electrochemical education, 2014,(5):39-41

[5] huang ronghuai, liu xiaolin, du jing, the influence factors of education information promotion foundation education reform [J]. China electrochemical education, 2016, (4) :2-5

[6] shen jian. The current situation and future development strategy of basic education informationization in jiangsu province [J]. China electrochemical education. 2009, (12).

[7] Zhao Jianhua Jiang Yinjian, Yao Pengge, li (. To prepare for the future of learning: reshaping the role of technology in education, the national education technology plan (NETP2016) interpretation [J]. Journal of modern distance education research, 2016, (2) : 5-15

[8] gong zhiwu, wu di, Chen Yang jian et al. New media alliance 2015 horizon report higher education [J]. Modern remote education research, 2015,(2):3-15. 